\title{
O universo visual dos xamãs wauja (Alto Xingu)
}

\section{Aristóteles Barcelos Neto}

\section{CpenEdition}

\section{Journals}

Edição electrónica

URL: http://journals.openedition.org/jsa/1958

DOI: 10.4000/jsa. 1958

ISSN: 1957-7842

\section{Editora}

Société des américanistes

Edição impressa

Data de publição: 1 Janeiro 2001

Paginação: 137-160

ISSN: 0037-9174

\section{Refêrencia eletrónica}

Aristóteles Barcelos Neto, " $\mathrm{O}$ universo visual dos xamãs wauja (Alto Xingu) », Journal de la société des américanistes [En ligne], 87 | 2001, mis en ligne le 17 novembre 2005, consulté le 30 avril 2019. URL : http://journals.openedition.org/jsa/1958 ; DOI : 10.4000/jsa.1958 


\title{
O UNIVERSO VISUAL DOS XAMÃS WAUJA (ALTO XINGU)
}

\author{
Aristóteles BARCELOS NETO *
}

Este artigo aborda a questão das experiências visuais dos sonhos e transes dos xamãs como elementos de uma conceitualização das quatro principais alteridades extra-humanas (" genteanimal », " roupa », « monstro » e « animal ») e das suas relaçòes com os Wauja. As imagens inseridas no texto derivam da reffexão ontológica e artística de um grupo privilegiado de indivíduos, aos quais são atribuídos relevantes poderes de interpretação dos fatos e de expressão visual e verbal das idéias cosmológicas wauja.

Palavras-chavB : Alto Xingu, índios Wauja, xamanismo, feitiçaria, imagem, cosmologia.

\section{L'univers visuel des chamanes wauja (Haut-Xingu)}

Cet article aborde la question des expériences visuelles des rêves et des transes des chamanes considérées comme éléments de conceptualisation des quatre principales altérités extrahumaines (" homme-animal », " vêtement ", « monstre » et " animal ») et de leurs rapports avec les Wauja. Les images insérées dans le texte résultent de la réflexion ontologique et artistique d'un groupe privilégié d'individus auxquels sont attribués des pouvoirs concernant l'interprétation des faits et l'expression visuelle et verbale des idées cosmologiques wauja.

MOTS CLÉs : Haut-Xingu, indiens Wauja, chamanisme, sorcellerie, image, cosmologie.

\section{The visual universe of Wauja shamans (Upper Xingu)}

This paper analyses the shaman's visual experiences in dreams and trances as elements in the conceptualisation of the four main types of non-human beings ( " monster, " and " animal ») and of their relationships to the Wauja. The pictures included in the article derive from the ontological and esthetic reflexions of a privileged group of individuals. These individuals are recognized as possessing specific powers for interpreting facts and visual or verbal expressions of Wauja cosmological ideas.

KBY wORDS : Upper Xingu, Wauja Indians, shamanism, witchcraft, imagery, cosmology.

* Programa de Pós-Graduaçào em Antropologia Social, Faculdade de Filosofia, Letras e Ciências Humanas da Universidade de São Paulo. Av. Prof. Luciano Gualberto 315, São Paulo - SP 05.508-900 Brasil. e.mail : barcelosneto@bol.com.br

Journal de la Société des Américanistes, 2001, 87 : p. 137 à 160. Copyright $($ Société des Américanistes. 
Beyond the Milky Way: Hallucinatory Imagery of the Tukano Indians (ReichelDolmatoff 1978) é talvez o primeiro livro a revelar de modo amplo o universo visual dos xamãs, nas terras baixas da América do Sul, e a apontar um promissor caminho de investigação etnológica na região ao integrar analiticamente expressões visuais e cosmologia. Este caminho, embora pouco trilhado, tem trazido contribuições interessantes ${ }^{1}$. O presente artigo, inspirado por essa tradição de pesquisas na Amazônia, descreve alguns aspectos da experiência visual entre os xamãs wauja e seus desdobramentos sobre as noções de imagem, alteridades extra-humanas, feitiçaria e doença, como noções-chave para uma aproximação preliminar dos pensamentos estético e cosmológico desse grupo xinguano.

Os Wauja ${ }^{2}$ habitam as proximidades da lagoa Piyulaga, a qual se liga por um canal à margem direita do baixo curso do rio Batovi, un dos formadores do rio Xingu, no estado do Mato Grosso, Brasil. Aproximadamente 263 pessoas ${ }^{3}$ residem em uma única aldeia circular com o sistema de praça central e casa das flautas. Falantes de uma língua maipure do tronco arawak, os Wauja constituem, juntamente com os Mehinako, os Yawalapíti, os Pareci e os Enawene Nawe, o grupo dos Arawak centrais (Franchetto 2001).

Segundo hipótese de Urban (1992), os Arawak teriam como centro de sua dispersão original a região das cabeceiras dos rios da bacia amazônica que nascem nos piemontes andinos da Bolívia e do Peru, conforme uma profundidade cronológica de 3000 anos ou mais antes do presente. Urban supõe que os Arawak-Maipure tiveram duas direções migratórias básicas : uma em direção ao sul e outra, ao norte amazônico, conservando-se sobretudo na periferia da grande bacia (Urban 1992, p. 95).

As investigações arqueológicas recentes (Heckenberger 1996 e 2001) sobre a formação da cultura xinguana apontam que os grupos arawak teriam sido os primeiros a se estabelecerem na região do Alto Xingu por volta de 800-900 A.D. Os Wauja contemporâneos são descendentes desses Arawak antigos, responsáveis pela formação da civilização das imensas aldeias circulares e fortificadas que surgiu na periferia meridional da Amazônia entre os anos 1000 e 1450.

Os Wauja integram, juntamente com outros nove grupos de diferentes filiações lingiiísticas, um sistema social multiétnico existente na região do Alto Xingu desde pelo menos os meados do século XVIII. Embora partilhem de um mesmo sistema sociocultural, os xinguanos distinguem-se etnicamente uns dos outros, seja pela língua (no Alto Xingu são faladas duas línguas do tronco tupi, duas do tronco arawak, duas do família carib, além do trumai, que é uma língua isolada), pela especialização tecnológica (conhecimento e efetiva utilização das técnicas de fabricação da cerâmica, dos instrumentos musicais, dos trançados, dos arcos e dos adornos corporais), ou por práticas específicas no âmbito dos rituais e da chefia. Tal profunda e variada diferenciação lingüística entre os povos xinguanos, todavia, não impede que haja entre eles eficientes mecanismos de comunicação ; os quais ocorrem, acima de tudo, em níveis supra-lingüísticos, notadamente nos planos do ritual, dos intercasamentos, das trocas de artefatos, da pintura e ornamentação corporais, da feitiçaria e do xamanismo ${ }^{4}$.

Este artigo tem seu foco especialmente voltado para os xamãs conhecidos como yakapá, literalmente « aquele que corre semiconsciente » para resgatar as almas dos doentes. A habilidade de resgatar almas está indissociavelmente ligada à visão (adivinhação) das doenças e dos seus agentes humanos e/ou extra-humanos, estes 
últimos denominados yerupoho ${ }^{5}$ e apapaatai (vide a seção 3 para uma explicação sobre estas noções). Os yakapá constituem grupos muito pequenos em cada aldeia. Entre os Wauja, por exemplo, são quatro, um número elevado se compararmos com as demais aldeias xinguanas, nas quais geralmente apenas um ou dois indivíduos possuem iniciação no xamanismo visionário-divinatório ${ }^{6}$. Tornar-se yakapá é uma tarefa árdua e de longuíssimo aprendizado, o que por vezes resulta em uma aldeia ficar alguns períodos sem seu « xamã de ver e ouvir » (Menezes Bastos 1984-1985), levando seus habitantes a solicitar os serviços de um yakapá de outra aldeia.

Uma sessão xamânica de yakapá na aldeia wauja é um evento para o qual converge a atenção não apenas dos familiares do doente, mas também de crianças e adultos curiosos de outras unidades residenciais. Ao assistir à performance divinatória e à extração dos feitiços e ouvir do yakapá as respostas sobre as causas e os agentes de uma doença, os indivíduos comuns (não-yakapá) aprendem e têm confirmados os fundamentos básicos da cosmologia do grupo. Esta é uma das principais posições que o xamanismo ocupa na sociabilidade xinguana, assim efetivada por ser ele um vigoroso sistema nativo de interpretação cosmológica. Vejamos a seguir como as experiências visuais contribuem para essa dimensão interpretativa do xamanismo wauja.

\section{A VISÃo PRIVILEGIADA : FUMAR, SONHAR, CURAR}

A discussão sobre os significados das relações entre o corpo e os modelos de percepção e de expressão é um assunto ainda pouco explorado pela etnologia indígena da Amazônia e do Brasil central. Num famoso livro de Seeger (1981) sobre a cosmologia suyá - o primeiro a abordar o assunto de modo sistemático na região -, três capítulos são dedicados ao entendimento das ênfases simbólicas que essa sociedade jê confere aos órgãos de sentidos e às experiências sensoriais e expressivas a eles relacionadas. Tais ênfases, segundo Seeger, podem definir importantes princípios das noções sócio-cosmológicas da sociedade em foco. O campo da visão, por exemplo, permite explorar as redes sociais, os processos de elaboração das identidades pessoais e étnicas e as percep̧̧ões dos ameríndios sobre os seus contatos com as alteridades extra-humanas, muitas delas, segundo os nativos, de existência « invisível ». Entre os Wauja essa premissa não seria diferente. Um contraste etnográfico Suyá-Wauja possibilita uma interessante abertura sobre a questão.

Para os Suyá, a visão é o sentido que está no mais alto nível da anti-sociabilidade, sendo também associada a uma moral e poder repugnantes. Uma visão extraordinária, como a dos feiticeiros (wayanga), é algo absolutamente nefasto. Tal visão pode ser adquirida quando um indivíduo age de modo « imoral », ou seja, quando ele, ao longo de sua vida, passa por sucessivos fracassos no processo de aquisição da perfeita audição, que, no sentido suyá, compreende ao mesmo tempo " ouvirentender-conhecer »- uma equação que aponta para o compartilhamento das normas sociais hegemônicas do grupo. Assim, para os Suyá, uma extraordinária visão jamais poderia conviver com a audição perfeita, pois, à medida que a primeira adquire traços vigorosos, a segunda se enfraquece e dá lugar a um indivíduo próximo ao mundo natural, ao mundo dos seres de visão aguçada, das coisas ameaçadoras e associais (Seeger 1981, p. 80-91). 
Diferentemente dos Suyá, a visão entre os Wauja estrutura-se simbolicamente através de uma escala hierárquica e de um padrão relacional do tipo interior-exterior que se manifesta, sem ser rigidamente dicotômica, na produção simbólica de um mundo « invisível » (o dos agentes patogênicos, ou seja, o das alteridades extrahumanas) e na produção da sua visualidade concreta, constituída por desenhos, artefatos, pinturas e adornos corporais, máscaras e flautas. A fim de melhor definir esse padrão, separo dois aspectos sociais da visão, um ligado às atividades da vida cotidiana e outro aos estados especiais do sonho, do transe, da doença e dos rituais. Limito-me aqui a explorar o segundo aspecto, que, a rigor, relaciona-se (1) às possibilidades de ver o que possui alto valor estético e por isso exibido / executado com pouca freqüência, (2) aos que estão livres das proibições visuais que marcam as diferenças de gênero, (3) à capacidade de ver o que é raramente visível ou num certo sentido «invisível » e (4) ao que só pode ser visto por quem adquiriu habilidades especiais ou por quem se encontra num estado de liminaridade.

As quatro situações apontadas acima são apenas uma esquematização para que o leitor não confunda as esferas privadas e públicas da experiência visual, as quais, entre os Wauja, são rigorosamente separadas e hierarquizadas : quanto maior é o ocultamento visual, maiores são o poder, o perigo e a importância da coisa ocultada. $O$ campo do adoecimento é um excelente exemplo disso. Na privacidade de sua doença, o doente tem a oportunidade de ver, através de seus sonhos, o que está lhe causando o mal, mas o doente só vê imperfeitamente o(s) agente(s) de sua doença. A identificação correta cabe apenas aos xamãs, os ocupantes privilegiados do topo da hierarquia da visão.

Em razão, dentre outras coisas, do seu papel fundamental na cura e na identificação de feiticeiros, a visão é o sentido do poder acusatório, às vezes manifestando-se de forma «nefasta »; e a categoria social que melhor representa este poder, nos mais amplos domínios, é o yakapá. Essa visão perfeita e acurada a serviço do bem-estar do doente e do faccionalismo político ${ }^{7}$ é adquirida graças às relações amistosas que os xamãs desenvolveram com os seus « apapaatai auxiliares » (ĩyakanâu, em wauja) e ao prolongado e intenso uso do tabaco (hoká), a substância máxima da atividade xamânica ; o yakapá fuma " para entrar luz nos olhos e para ele ver ».

Ao tabaco estão associados os poderes terapêuticos restauradores e de comunicação com o « sobrenatural » : « o cheiro de hoká agrada aos apapaatai, faz eles ficarem alegres ». Parte do poder de curar do yakapá advém da possibilidade de "ver o feitiço », ou seja, no diagnóstico os sintomas da doença não são de todo significativos para determinar a(s) causa(s) da mesma, o que importa de fato é descobrir qual o apapaatai ou, no caso de feitiço humano, qual o feiticeiro que está causando o malefício ao doente, para então se prosseguir com a cura.

O tabaco usado pelos Wauja é plantado nas imediações das roças de mandioca. Cada xamã tem sua pequena plantação particular de onde colhe as folhas que são colocadas para secar no interior da sua casa, próximas ao seu local de dormir. Depois de secas, as folhas são guardadas em uma bolsa (tuapi) especialmente confeccionada pelas mulheres para o uso dos xamãs. A bolsa é feita a partir do encordoamento de fios de algodão nativo, tingidos de vermelho, com finas lascas de buriti. Esta matériaprima freqüentemente é mencionada nas passagens dos mitos que relatam a fabricação de « roupas sobrenaturais » por seres humanos ou extra-humanos. A tuapi tem 
ainda o objetivo de guardar os cigarros, o chocalho e pequenos objetos que o xamã usa quando vai à casa de alguém ministrar seus serviços de adivinhação e cura.

Por vezes, quando alguém acumula grandes quantidades de tabaco, este pode ser trocado por outros produtos de valor ritual, como urucum e sementes especiais de uso dos xamãs. Os cigarros, que variam de 30 a $50 \mathrm{~cm}$ de comprimento, são enrolados exclusivamente com as folhas (hoká opana) de uma árvore (espécie não identificada) encontrada nas imediações da aldeia.

Na sociedade wauja, espera-se que todo homem em idade madura tenha aprendido a fumar, essa é uma prática socialmente valorizada que inspira o respeito dos mais jovens pelos mais velhos, e destes pelos seres extra-humanos (yerupoho e apapaatai), os donos do tabaco e das folhas que enrolam os cigarros. Fumar é uma atividade típica de quem aprendeu as tradições e obteve um razoável conhecimento do mundo "sobrenatural ». Cotidianamente, fuma-se com parcimônia e apenas em grupo na reunião diária que os homens fazem no pátio em frente à casa das flautas (kuwakuho).

$\mathrm{O}$ uso freqüente e moderado do tabaco estimula os sonhos - que são, do ponto de vista wauja, informações visuais e sonoras - sobre as alteridades extra-humanas. Ele é ainda a substância que possibilita aos yakapá terem a sua visão « duplicada », ou seja, permite que eles vejam simultaneamente o que está oculto no interior do corpo do doente (o feitiço) e o que é « invisivel » no exterior, isto é, os movimentos e as intenções dos apapaatai e yertupoho.

Nos sonhos, os xamãs ouvem músicas e, se são bons músicos, conseguem lembrar as melodias depois que acordam, procurando executá-las o mais rápido possível para não esquecê-las. Assim como o transe, o sonho também é uma experiência de comunicação com os apapaatai, a diferença é que o primeiro é intencionalmente provocado pela ingestão de tabaco e pela necessidade do diagnóstico. Mas no caso do sonho, o contato é espontâneo, o xamã não escolhe quando ou com o que vai sonhar. Ele pode sonhar várias vezes com o mesmo apapaatai, que pode se apresentar com características diferentes em cada sonho. Para um yakapá, sonhar com os apapaatai permite aumentar seu conhecimento do « sobrenatural » sem que para isso ele precise sofrer o impacto físico e emocional do transe. Nem tudo o que surge nos sonhos é perfeitamente reconhecido. Nas ocasiões apropriadas, os yakapá procuram esclarecer os questionamentos provocados por um sonho com um amigo mais experiente ou com o seu professor. O sonho é descrito como uma experiência, em geral, inócua. Mas nem sempre, no sonho, alguém está livre de um confronto direto ou de uma agressão de um apapaatai. Um episódio ocorrido durante meu trabalho de campo em 1998 ilustra bem como podem ocorrer tais confrontos.

No início da primeira etapa do trabalho de campo, pedi a um dos meus informantes, Aruta - um eminente xamã-cantor e contador de mitos - , que desenhasse para mim o Pulu Pulu ${ }^{8}$. Aruta não poupou detalhes e, com muito didatismo, fez o Pulu $P u l{ }^{9}$ com seus « donos » e as máscaras de Yakui, que acompanham a festa. Dois dias depois, voltei à sua casa para mais uma sessão de desenho. Aruta contou-me, então, o terrível sonho que tivera naquela noite : o Ulako apapaatai (peixe-elétrico monstro) $\mathrm{e}$ a Iyapu apapaatai (arraia-monstro) ficaram irritadíssimos com ele, o Ulako tinha um pedaço de pau para bater em Aruta, que corria com medo da surra. O motivo da tentativa de agressão, segundo ele, era muito simples : o Ulako e demais moradores do Pulu Pulu não gostaram de ter suas imagens reveladas. 
Enquanto instâncias de percepção de imagens figurativas, o sonho e o transe não proporcionam a amplitude de dados etnográficos necessários para o entendimento do status conceitual da imagem entre os Wauja. Como demonstra o exemplo acima, é sobretudo através da circulação das imagens (re)criadas ou reproduzidas sobre os mais variados suportes - desenhos em papel, fotografias, máscaras, cerâmica, bancos de madeira, etc. - que o arcabouço conceitual da imagem toma contornos mais sólidos e definidos.

Ver por intermédio do uso do tabaco é uma questão de coragem e de resistência física e mental. O trecho a seguir, narrado por um jovem mehinako, proporciona outros dados sensíveis sobre o tabaco e as gnosiologias arawak-xinguanas do feitiço.

O fumo «solta » (amolece, permitindo que saiam) os « bichos» que os Papan̂e colocaram dentro do doente ; Kaití (outro pajé) joga fumaça do fumo nas mãos reunidas, e depois a esfrega entre elas, vai diminuindo (o " bicho » [feitiço]) de tamanho, vai desmanchando, depois, ele limpa a palma das mãos no pau da casa. Tira-se mais do que um « bichinho », são vários. Quando Papañê [apapaatai] bota « bicho » para virar pajé (tornar o doente um pajé), ele roda «bicho » (em círculos conforme mostrou), « mexe muito », na palma da mão do pajé que o retirou do doente ; não deve tirar, porque se tirar não fica pajé ; mas dói muito, esse « bicho » é difícil de agüentar. Se a pessoa agüenta, demora bastante tempo doente, fica pajé, acaba melhorando com o tempo (Fénelon Costa 1988, p. 148).

Percebe-se claramente na narrativa acima que os xamãs possuem, dentro de si, feitiços « sobrenaturais » que são os próprios apapaatai em miniatura. Obtive vários desenhos explicativos nos quais os feitiços de apapaatai não têm mais do que dois ou três centímetros de comprimento. Os desenhos, referidos como imagens dos feitiços em si, eram todos minúsculas naĩ ( « roupas », um tipo particular de agência e de manifestação ontológica dos seres extra-humanos, conforme descrição na seção 3 deste artigo) introduzidas no corpo do doente através de projéteis lançados pelos apapaatai. Ampliando o sentido desta idéia, o feitiço parece ser constitú́do da própria substância vital / corporal do apapaatai responsável pela doença ${ }^{10}$, o primeiro é a " corporificação » miniaturizada do segundo. No trecho da narrativa transcrita acima, nota-se que para o doente tornar-se um xamã ele deve necessariamente ficar (suportar) com o feitiço do apapaatai em seu corpo. Os meus quatro informantes yakapá diziam, com freqüência, ter apapaatai dentro de si próprios, ou seja, dimensões miniaturizadas dos apapaatai que os adoeceram agora residem em seus corpos ${ }^{11}$, como auxiliares em suas curas e adivinhações ( $c f$. também Viveiros de Castro 1977). Enfim, os apapaatai e os seus feitiços estão no mesmo campo semântico, mantendo uma relação metonímica que perpassa as noções de corpo e substância vital.

Para os Wauja, e, segundo Fénelon Costa (1988, pp. 148-149), para os Mehinako, tanto os apapaatai quanto os feiticeiros podem fazer vítimas fatais. Ambos os grupos mencionam que os apapaatai podem ser incitados por « feiticeiros humanos » a atacar pessoas. A narrativa abaixo, feita por um jovem Mehinako em iniciação xamânica, esclarece certos aspectos das relações entre um « feiticeiro humano » e um feiticeiro apapaatai.

Kamínkia é feiticeiro. É preto. É pequeno (mostrou o tamanho de uma criança de 5 anos). Morrem cedo, até a idade de Kumatí (isto é, atingem cerca de 30 anos). Tem cabacinhas com todo feitiço, óleo de pequi, outros. Flechinha, arquinho com feitiço. Têm brincos com feitiço. Quando morre Kamínkia, se um feiticeiro (homem) o encontrou, dos seus ossos faz feitiço ainda 
mais forte. Se um feiticeiro o encontra no mato, troca com ele feitiços : um dá ao outro os feitiços que tem. Às vezes alguém morre, e é Kaminkia que matou, e os parentes pensam que é feiticeiro (Fénelon Costa 1988, p. 149).

$\mathrm{O}$ « sobrenatural » antropomorfo Kaminkia pode matar humanos com seus próprios feitiços como com aqueles trocados com feiticeiros. Ou seja, há um trânsito de feitiços que se configura segundo as intenções dos agentes dos malefícios e que aponta para uma constante troca de substâncias entre esses dois mundos. Via de regra, uma troca extremamente perigosa para os humanos. Segundo os Wauja, o simples fato de ver determinados apapaatai ou ter contato com um pedaço da sua « roupa » é fatal para um humano comum (não-xamã). Por isso, "roupas » abandonadas no mato jamais devem ser tocadas e muito menos trazidas para a aldeia.

As noções de consubstanciação e transubstanciação fundamentam grande parte das explicações sobre a natureza e o modo de agência dos feitiços humanos e extra-humanos. No entanto, há algumas distinções especiais. Os primeiros utilizam-se de pequeninos objetos pessoais, restos de comida, excrementos, fios de cabelo, sangue, esperma ou outras substâncias da vítima alvo para se fazer o feitiço, que usualmente é embrulhado e escondido em locais por onde a vítima costuma transitar ${ }^{12}$. Ou seja, vêm da própria vítima as substâncias que lhe poderão matar; caso esta seja a intenção do feiticeiro. A mistura dessas substâncias é imbuída de intenções e sentimentos do feiticeiro que se fixam perfeitamente na matéria, assim o feitiço passa a ter força própria, por isso ele não precisa ser introduzido no corpo da vítima. Os feitiços humanos devem ser externos e ocultos para que a sua identificação e posterior neutralização sejam dificultadas. Enfim, tanto os feitiços humanos quanto extrahumanos são forças-substância que impulsionam movimentos involuntários da alma para fora do corpo ; se irreversíveis, esses movimentos são considerados « assassinatos $»$. Desse modo, toda desencarnação humana é vista como a agência de outrem.

Para se obter uma eficácia terapêutica nos casos mais graves de adoecimento, além da extração dos feitiços e da recuperação da alma (ou substância vital, paapitsi), é imprescindível a organização de uma festa para o(s) apapaatai causador(es) da doença. As festas de apapaatai podem ser aproximadas a um tipo de terapia estética, sendo a cura a restauração da beleza. A participação do doente na festa não é significativa para sua cura, e nem ele precisa receber ornamentação ou atenção artística específica para ser curado, como ocorre entre alguns grupos Pano (GebhartSayer 1986).

A contrapartida do apapaatai que foi celebrado é proteger a pessoa que ele atacou de prováveis investidas de outros apapaatai. Assim, o doente-patrocinador da festa sai mais fortalecido, não apenas quanto às suas relações com o « sobrenatural », mas sobretudo porque ao se tornar dono de uma festa de apapaatai ele passa a participar de uma rede de prestações e contra-prestações de serviços rituais em sua aldeia.

$\mathrm{O}$ ex-doente deverá oferecer a festa do seu apapaatai protetor de acordo com um ciclo mais largo, do qual a periodicidade pode variar entre alguns meses ou vários anos, por isso ele terá que cuidar das flautas, clarinetes ou máscaras dos apapaatai, que então lhe pertencerão e que ficarão em sua casa ou na kuwakuho. As flautas são preservadas com extremo cuidado, mas as máscaras são guardadas até se deteriorarem ou até o momento adequado para a sua queima. 
No contexto da sensorialidade xamânica, a visão e a audição parecem ter uma alta complementaridade. A doença, a razão primordial da provocação do transe por intoxicação por tabaco, abre um canal de comunicação com as alteridades extrahumanas que permite o diagnóstico. Enquanto a visão está mais voltada para o diagnóstico - ver : descobrir : revelar -, a audição (a música no caso) está relacionada à expansão do evento em que se insere a cura, abrindo um outro canal de conunicação com o "sobrenatural », que se expressa sobretudo na festa. Não quero dizer com isso que as artes visuais são menos importantes do que a música na estruturação das festas de apapaatai. Estas dependem da produção de pinturas corporais e de artefatos para assegurar os estados de alegria e beleza propícios ao estabelecimento das relações amistosas com os apapaatai; digamos, sem deixar de lado a « amizade forçada », que essas relações são também de « domesticação ». Na sócio-lógica wauja, os inimigos podem ser « conquistados » com a oferta de comida e com prazeres estéticos.

Em situações de doenças graves, a realização de uma sessão de cantos xamânicos (pukayekene) tem por objetivo tirar enormes quantidades de feitiços do corpo do doente. Além dos cantos, faz-se o uso de chocalhos (Coelho 1988), instrumentos de imenso poder terapêutico. Segundo observações de Mello (1999, p. 182), « a cura de um doente está relacionada à satisfação do Apapaatae com a música ». Mas não só isso : as músicas de pukayekene agem como extratores dos objetos patológicos.

Nas festas de máscaras e flautas de apapaatai, a música tem o papel preponderante de concluir um ciclo de comunicação que se inicia de um modo muito restrito, a partir da experiência visionária do yakapá e do doente. Este processo de comunicação alarga-se com a festa ao envolver o resto da comunidade num evento em que música, drama, dança, máscaras (naĩ) e ornamentação corporal integram, de modo temporário e eufórico, um ser « sobrenatural » entre os Wauja.

Para os xamãs atuais, os seus próprios adoecimentos graves foram as situações « pró-xamânicas » que acenaram para as suas alianças com os apapaatai. De acordo com a coragem, vontade, aspiração e resistência do doente ele passa a ser um xamã. Dos apapaatai que o adoeceram especificamente ele receberá fortes auxílios em seus desafios divinatórios e seguras orientações pelos caminhos dos mundos « invisíveis ». De resto, o doente que se tornou xamã precisará aperfeiçoar seus conhecimentos e poderes com professores de xamanismo, para quem os pagamentos deverão ser muito generosos, caso contrário o aprendizado não ocorrerá.

Essa relação de reciprocidade, mantida entre o doente, o xamã e os apapaatai, demonstra que estes últimos não são simplesmente monstros ferozes ou inimigos dos humanos. São, sim, ferozes, embora potencialmente amistosos. A reversão da agressão dos apapaatai em aliança dependerá das habilidades dos xamãs em negociar a alma roubada e oferecer festas (leia-se comida, alegria e beleza) aos apapaatai. A reversão das atitudes de medo e respeito, que os Wauja normalmente têm para com os apapaatai, para atitudes de amizade e intimidade é um negócio político, um tipo de diplomacia xamânica com as alteridades "sobrenaturais ». O resgate da alma do doente é a política cósmica (Viveiros de Castro 1996) em um dos seus mais altos níveis de manifestação.

Embora o adoecimento grave, em conseqüência do roubo da alma, seja indesejável e cause muito medo, ansiedade e tristeza ao doente e demais membros da comunidade, 
essa parece ser a única situação concreta que cria as condições para um provável futuro contato amistoso entre o doente e os agentes de sua doença. $\mathrm{O}$ adoecimento $\mathrm{e}$ a intervenção xamânica operam no sentido da inclusão do outro e da sua « domesticação », cujo processo se inicia com uma guerra que envolve o roubo das almas humanas, as quais são simultaneamente a imagem e a substância vital das pessoas.

\section{POTALAPITSI E PAAPITSI: AS NOÇÕES DE IMAGEM E ALMA}

O termo potalapitsi expressa a idéia de « uma cópia fiel » construída à maneira de uma imagem figurativa. No entanto, potalapitsi tem significados muito mais amplos, sendo uma noção básica para o entendimento da cosmologia wauja. Entre os Yawalapíti, Viveiros de Castro (1977, p. 122), procurando identificar concepções nativas sobre símbolo, chegou à noção de pitalatisi (figura, desenho, fotografia, imagem), que também poderia ser traduzida por forma. Gregor, entre os Mehinako, aproximou-se com precisão do contexto que revela o significado da noção de imagem :

Meus professores tentavam, muitas vezes, por meio de mapas ou figuras, patalapiti, fazer-me compreender o que estavam falando. Um patalapiti é a representação de algo que é real, e a própria representação contém uma realidade em si mesma (grifo meu). A figura de um espírito pode ser perigosa porque, como todas as figuras, inclui pelo menos alguns traços que definem o que é real, substancial, tais como forma ou espaço (Gregor 1982, p. 38).

Ao que tudo indica, potalapitsi, pitalatisi e patalapiti são termos cognatos, apontando para a mesma noção, ou grupo de noções.

Entre os Wauja, na mesma medida em que as imagens podem dar existência a algo antes inexistente, elas também podem vivificar e presentificar seres que já existem, mas que só podem ser vistos pelas pessoas comuns (não-yakapá e não-doentes graves) a partir da elaboração «artística 》 deles, o que em geral acontece nos rituais de máscaras e flautas. Desenhos ou máscaras de apapaatai integram a ordem da miniaturização (ou do modelo reduzido, como denomina Lévi-Strauss em $O$ pensamento selvagem, 1989), não são metáforas nem meras representações. As máscaras são a invisibilidade tornada visível. Trata-se mais de um estado de transformação das sensibilidades perceptivas do que da representação no sentido mais convencional que esta possui na filosofia ocidental. A noção de potalapitsi opera no nível da réplica. Para os Wauja, a imagem vivifica aquilo que se confeccionou ou desenhou, esta é uma das razões pelas quais produzir objetos artísticos nessa sociedade é algo tão sério e perigoso, e está reservado, mas não exclusivamente, a pessoas que mantêm alguma relação privilegiada com o « sobrenatural ».

Os Wauja identificam dois tipos de alma : a « alma-sombra » (yakula) e a « alma do (ou no) olho » (ojutai ogamawato). Este artigo aborda apenas a segunda, que é também entendida como substância vital (paapitsi). Nos níveis abstratos, essa alma é a consciência e a memória, no nível concreto ela se manifesta enquanto um refiexo do ser no centro de cada olho. A noção alma-olho / alma-consciência / substância vital é homóloga à noção de imagem, sendo também uma das peças fundamentais para a explicação dos estados de transe, sonho, adoecimento e morte, pois a paapitsi é a alma " frágil » que pode se descolar do corpo, daí a relativa facilidade com que os apapaatai a roubam; em casos extremos, a demorada ausência da paapitsi pode levar o corpo da 
pessoa à morte : eis a estreita dependência de vitalidade que o corpo possui com a alma.

Do ponto de vista dos humanos, as suas almas são o principal alvo de ataque dos apapaatai e yerupoho, mas para estes o ataque reveste-se de outro sentido : é a única forma de criar as condições de uma reciprocidade forçada com os humanos, os detentores dos alimentos e da tecnologia que outrora foram deles (vide explicações na seção seguinte).

Não é exatamente a alma que é «frágil », e sim o corpo, este sendo incapaz de sobreviver sem aquela. Os Wauja acreditam que o corpo humano não resiste a um contato prolongado com os apapaatai e yerupoho - ou seja, quando os seus feitiços não são extraídos -, mas a alma pode viver entre eles, para todo o sempre, na mais plena segurança e satisfação. Essa flexibilidade ontológica, representada pela extraordinária mobilidade da alma, conduz a uma mudança de perspectiva : a alma se vê gradualmente ressocializada entre os monstros.

A literatura da região faz algumas referências ao uso de spirit catchers materializados por bonecas de fibras vegetais (ĩyãu opotalapitsi, em wauja; yakulátsa, em Yawalapíti ; kefegé, em kuikuro e ta'angap, em kamayurá). De acordo com as etnografias de Carneiro (1977), Viveiros de Castro (1977) e Menezes Bastos (1984-85), o xamã defuma a boneca : ela está, então, potencialmente viva para alojar temporariamente a alma roubada ao doente. Em seguida, a boneca é levada até onde se encontra o apapaatai, que está em posse da alma do doente. Carneiro narra um caso dramático em que um yakapá Kuikuro mergulha abraçado a uma boneca kefegé até o fundo da lagoa para recuperar a alma roubada de um paciente (Carneiro 1977, pp. 220-222). Depois de um esforço colossal o xamã consegue tomar a alma do apapaatai e colocá-la na boneca. Esta contém agora a substância vital do doente. Por um processo de transubstanciação, a boneca torna-se a imagem viva do doente. $O$ xamã carrega a boneca fortemente abraçada ao seu peito até a aldeia, para então transferir a alma que está na boneca para o corpo do doente. $\mathrm{O}$ uso de bonecas spirit catchers também é relatado entre os Mehinako, que têm procedimentos muito semelhantes aos descritos acima (Gregor 1982, p. 313).

A questão da imagem humana envolve outros contextos além da cura xamânica. Segundo Coelho (1991-92, p. 61), os Wauja consideram perigoso conservar fotografias das pessoas que já morreram. É recomendada a destruição dos seus retratos para que a viagem da alma do morto, até a aldeia celeste, não seja impedida ou retardada. Ao longo do trabalho de campo, pude observar uma enorme evitação quanto ao retrato na arte wauja : todos os informantes recusavam o pedido de que desenhassem algum de seus parentes ou amigos xinguanos, no entanto, obtive facilmente retratos desenhados de índios não-xinguanos e de uma estrangeira, que foram objetos de muitos risos. A conclusão de Coelho (1991-92, p. 61) de que « retratos são dotados de uma força viva, como se de certa maneira duplicassem a pessoa dos retratos", corresponde plenamente à idéia wauja, presente em diversos contextos, da difícil dissociação entre alma e imagem.

A cultura xinguana desenvolveu uma especial necessidade simbólica de transformar imagens figurativas bi ou tridimensionais em algo vivo ou potencialmente vivo : os atos do demiurgo Kwamutõ e de seus netos Kamo e Kejo (os irmãos gêmeos Sol e Lua) ao criarem os primeiros humanos ${ }^{13}$, os atos dos xamãs ao confeccionarem as 
bonecas spirit catchers, as efígies dos mortos no Kaumai, o ta'angap do ritual Yawari ou as máscaras de apapaatai são alguns dos exemplos mais visíveis. Conforme as etnografias dos rituais, pode-se dizer com certa segurança que são os sentimentos de proximidade, compartilhamento, reciprocidade e reconciliação que estão a orientar o sentido simbólico da produção dessas imagens.

\section{A TEMÁ́TICA DAS IMIAGENS}

As descrições cosmológicas a seguir baseiam-se amplamente nos desenhos que tematizam os seres extra-humanos, feitos, em sua maioria, pelos xamãs visionários ( vakapá), de acordo com a tradição iconográfica das máscaras e da ornamentação da cultura material wauja, embora com elaborações formais muito mais sofisticadas.

Assim como o mito, o desenho expressa uma percepção particular da temporalidade, pois o que se vê sobre o papel são as réplicas de antiquiíssimos seres que os Wauja consideram ter atravessado a fronteira que separa a humanidade da animalidade / monstruosidade. Em sua história remota, esses seres extra-humanos complexificaram-se, com real intenção, devido ao desvairado medo que tiveram do cataclismo original. Confusos e sem a possibilidade de conservarem todos os traços sociais e morais que os humanizavam, eles acabaram ficando presos num mundo de ambigüidades ontológicas e de poderes nefastos dificilmente controláveis. Vejamos a seguir alguns detalhes sobre como os desenhos desses seres foram feitos.

Nota-se na rapidez, na precisão e na fluidez dos traços, mas sem um esquematismo rígido e estéril, uma plena certeza das formas e do modo de construção do espaço plástico. Tais manifestações expressivas são análogas à fluidez discursiva observada nas narrativas míticas. Estes dados reforçam a idéia de que os desenhistas não têm dúvidas ou inseguranças sobre o que eles colocam no papel, e que os desenhos possuem uma correspondência complementar em relação aos mitos. Portanto, os desenhos não são « ilustrações » dos mitos, e nem os mitos « legendas » dos desenhos. Embora exista essa complementaridade, ela não ocorre de modo automático, pois os desenhos assumem um status independente, constituindo um campo reflexivo próprio sobre as alteridades extra-humanas.

Percebi, desde as primeiras folhas preenchidas, que os desenhistas não faziam grandes esforços mentais para produzir os desenhos, provavelmente, porque as reffexões já foram feitas muito antes. O papel, neste caso, não é muito mais do que o suporte final de transferência da imagem outrora reservada ao mundo dos sonhos, transes e mitos. Ao fazer a transposição das imagens oníricas para o papel, os yakapá estão abrindo, a partir de múltiplos espectros interpretativos pessoais, a «caixa preta " que é o mundo dos sonhos e dos transes, mas, sobretudo, traçando uma ontologia e uma cosmologia. Penso que se não houvessem possibilidades de expressar tais imagens oníricas plasticamente, seu conceito visual (imagem mental) continuaria existindo e tendo extrema importância para os xamãs. A figuração dos apapaatai, yerupoho e animais é o resultado (1) do exímio domínio sobre as formas tradicionais de expressão visual (trançado, pinturas corporais e de artefatos, entalhe e modelagem), (2) de uma imensa curiosidade sobre a adaptação de processos formais, sobre a anatomia, a etologia e a metamorfose dos animais, (3) de exercícios mnemônicos, e (4) de uma certa liberdade de criação e interpretação plásticas. 
Nesse contexto de (re)criação das imagens das alteridades extra-humanas (e aqui não me refiro apenas às imagens bidimensionais, mas às máscaras de festas também), deve-se ter claro que os apapaatai e seus conhecimentos artísticos (pinturas, ornamentos, danças, músicas, festas) são sempre descobertas pessoais : a experiência profunda com o « sobrenatural » é essencialmente de ordem individual ${ }^{14}$. Daí os desenhos dos apapaatai e yerupoho circunscreverem-se a uma esfera relativamente idiossincrática de " representação » visual. No entanto, as muitas variações interpretativas individuais não se apresentam enquanto realizações isoladas ou contraditórias, elas são, cada uma, pontos de vista complementares e intercomunicantes. Assim cada informantedesenhista, através de suas magníficas e variadas expressividades, contribui para a constituição de uma iconografia do cosmo wauja que extrapola a dureza das exegeses e avança sobre os campos da criatividade e da imaginação onírica.

Na vida wauja, há uma presença permanente e ampla de seres extra-humanos que remonta ao tempo em que os animais eram gente e falavam. Um dos princípios em que se baseia essa presença permanente é o elo contínuo entre os apapaatai $\mathrm{e}$ os animais. $\mathrm{O}$ elo mencionado atinge os Wauja cotidianamente, sobretudo, através de seu sistema alimentar e das teorias do adoecimento e do sonho. Passemos à descrição dos terríveis, belos e feios personagens dessa ontologia plástica a partir das interpretações plásticas dos yakapá.

Nos primórdios dos tempos, uma profunda escuridão reinava sobre o mundo. Na superfície da terra, viviam os yerupoho, seres antropomorfos ou zooantropomorfos (Figuras 1, 2 e 3), e, dentro dos cupinzeiros, viviam os humanos (i.e. os antepassados dos Wauja), na mais absoluta penúria de bens culturais: fogo, panelas, cestos, comidas, etc.

Num certo dia, os yerupoho ouviram anunciar que os heróis culturais dos Wauja fariam o astro solar aparecer definitivamente no céu. Apavorados com a iminente mudança cósmica, os yerupoho lançaram-se num frenético trabalho de criação de indumentárias, máscaras e pinturas protetoras contra as ações deletérias e transformadoras irreversíveis do sol. Os yerupoho criaram indumentárias extremamente diversificadas, que na verdade não eram simples « roupas » (nã̃, em wauja) protetoras. Ao vesti-las, assumiram uma nova identidade, a identidade da « roupa », tornaram-se apapaatai : uma realidade ontológica que se perpetua desde então e que corresponde a diversas classes de animais vistos cotidianamente pelos Wauja, a uma série de artefatos rituais (flautas, clarinetes, trocano) e aos seres monstruosos (todas as figuras reproduzidas, exceto a de número 4), estes visíveis em situações especiais e liminares - sonhos de xamãs e de doentes graves, transes e morte — ou quando são feitas as suas máscaras por ocasião das festas de apapaatai. Os desenhos figurativos apresentados neste artigo são um caso excepcional de visualização ampla das alteridades « sobrenaturais ».

Dois tipos de transformação abateram-se sobre os yerupoho, que correspondem precisamente às duas categorias de apapaatai. Aqueles que conseguiram fazer e vestir a sua indumentária a tempo tornaram-se « roupas», que correspondem aos seres extra-humanos invisíveis e visíveis. Estes últimos são os animais propriamente ditos (mamíferos, peixes, aves, anfíbios, insetos, etc.) e os primeiros são as suas « duplicações sobrenaturais » que, no entanto, possuem uma natureza monstruosa ausente nos seres visíveis (vide explicações a seguir). Os yerupoho que ficaram «nus" foram 

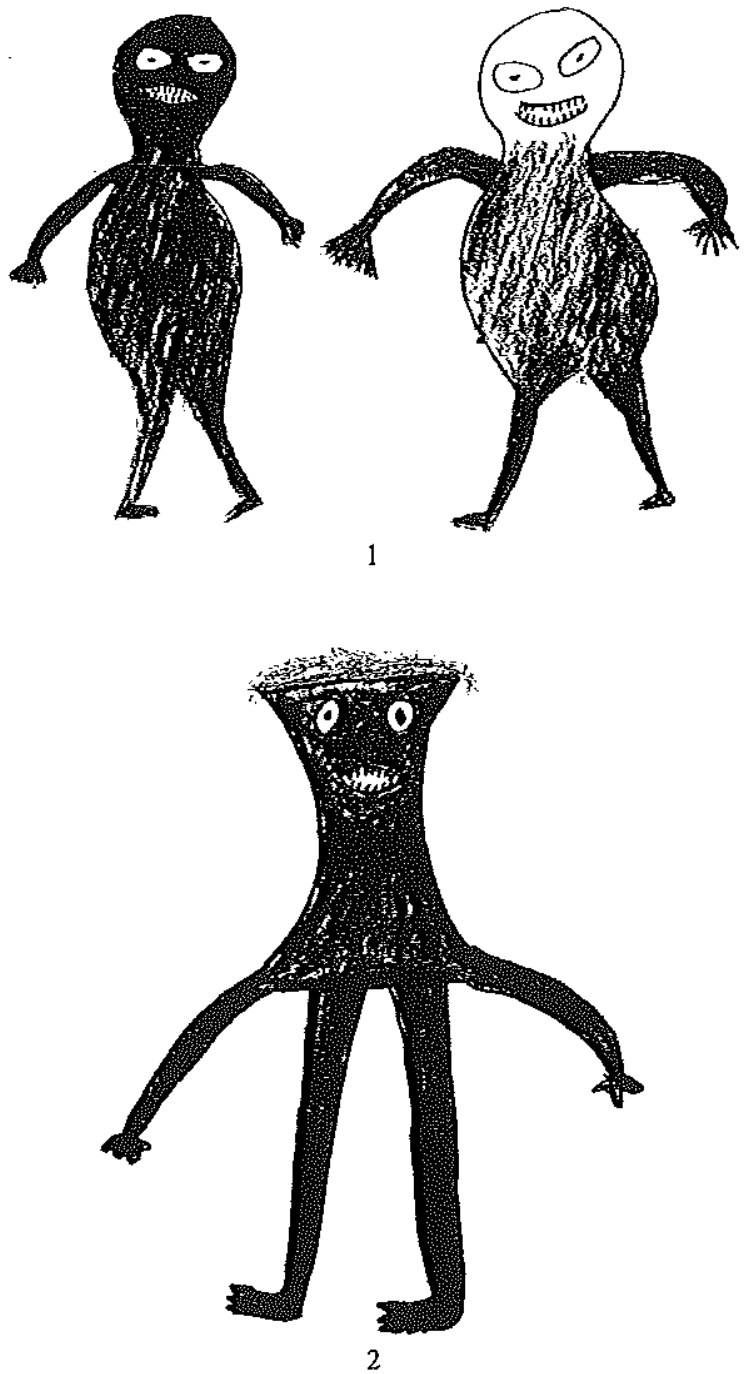

FIG. 1. - Nukãi kumã, yerupoho (casal de panelas monstro) Autor : Itsatutaku Wauja

Técnica : crayon s/ canson. Dimensões : $30 \times 50 \mathrm{~cm}$ Coleçào Aristóteles Barcelos Neto (1998)

FIG. 2. - Uwiwiyá kumã, yerupoho (monstro antropomorfo) Autor: Ajoukumã Wauja

Técnica : crayon s/ canson. Dimensões : $30 \times 50 \mathrm{~cm}$ Coleção Aristóteles Barcelos Neto (1998) 


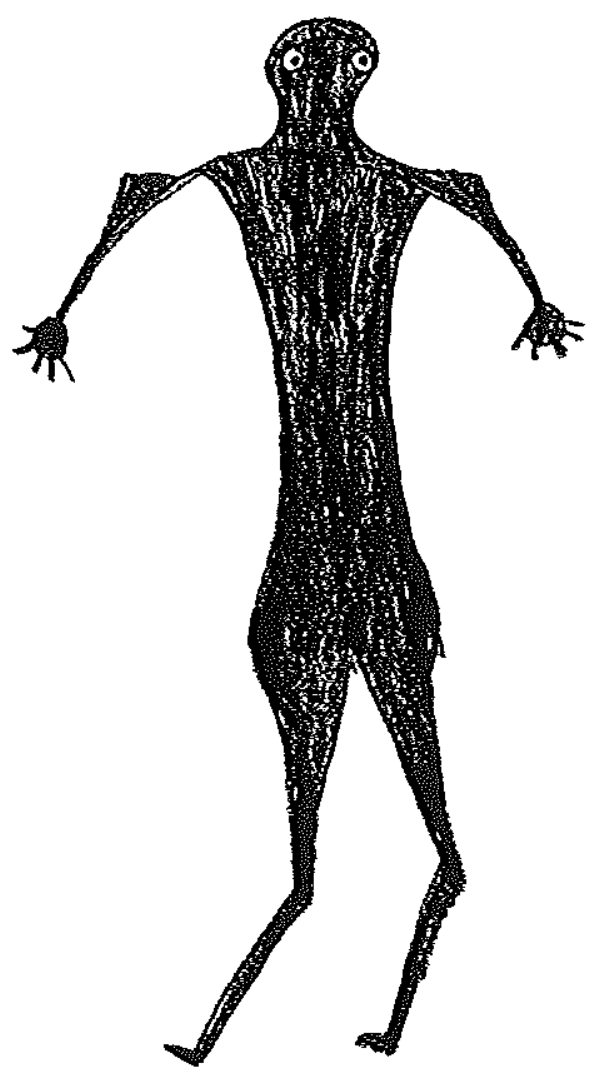

3

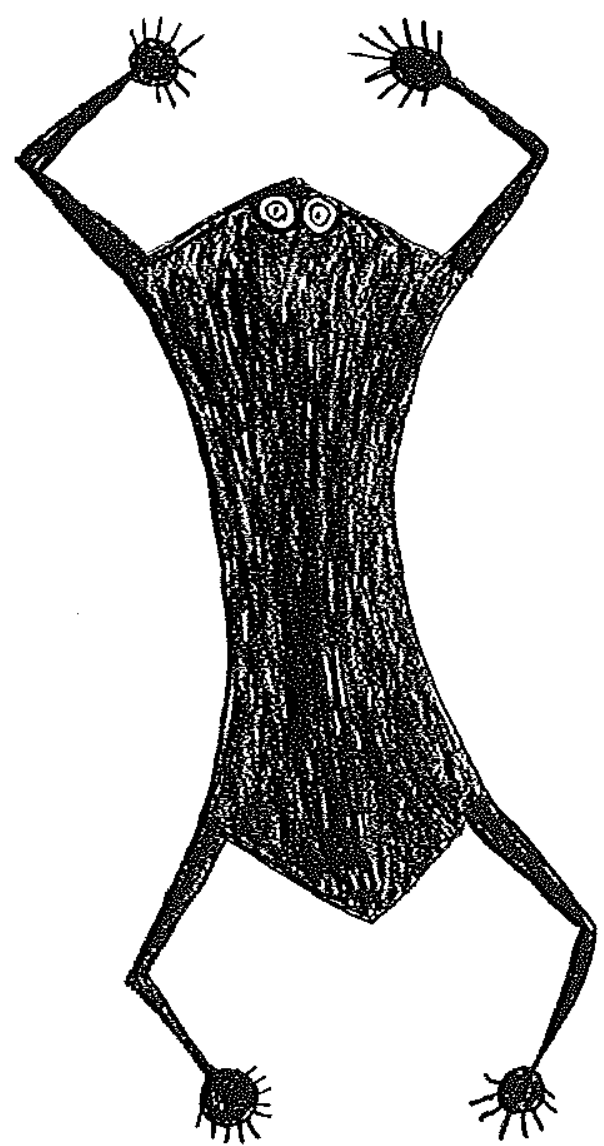

4

Fig. 3. - Eyusi ìyãu, yerupoho (gente-rà) Autor : Kamo IVauja

Técnica : crayon s/ canson. Dimensões : $25 \times 30 \mathrm{~cm}$

Coleção Aristóteles Barcelos Neto (1998)

FIG. 4. - Ey'usi (rã)

Autor : Kamo Wauja

Técnica : crayon s/ canson. Dimensòes : $30 \times 50 \mathrm{~cm}$

Coleção Aristóteles Barcelos Neto (1998) 
atingidos de maneira definitiva e drástica com o aparecimento do sol : tornaram-se apapaatai iyajo (apapaatai de verdade, ou seja, que não usam «roupas»), seres extremamente perigosos que devoram ou simplesmente matam seres mais fracos, dentre estes, os humanos.

Os apapaatai iyajo possuem uma identidade permanente fixada sobre o seu corpo através da ação transformadora do sol. Nukãi kumã (panela-monstro antropomorfa, Figura 1), Eyısi kumã (rã-monstro, Figura 5), Meyejo kumã (gambá-monstro, Figura 6), Mepelesi (sanguessuga-monstro, Figura 7) e Kãkãya kumã (gaivota monstro, Figura 8) são alguns dos inúmeros apapaatai iyajo existentes no cosmo wauja.

Quando os yerupoho, já vestidos com suas " roupas » viram que o dia estava clareando, a maioria lançou-se às águas, tendo como líder um trio de flautasapapaatai denominadas Kawoká. Eyusi («roupa » rã, Figura 9), Talapi kumã («roupa » peixe-clarinete, Figura 10) são exemplos dos milhares de «roupas » em permanente criação e movimento desde o surgimento do sol.

$\mathrm{O}$ modelo classificatório que começamos a esboçar aqui não é exclusivo aos Wauja, os Mehinako (Fénelon Costa 1988 e Gregor 1982) e os Yawalapíti(Viveiros de Castro 1977, 1978) também o seguem. Os Mehinako, em particular, são mais do que um grupo cognato aos Wauja : os lingüistas chegam a considerá-los como falantes de uma só língua (Franchetto 2001, pp. 115-117). As percepções desses três grupos arawak sobre os seres « sobrenaturais » apresentam correspondências bastante simétricas, conforme se pode notar nas descrições de Gregor :

Os apapãiyei [apapaatai, em wauja] podem aparecer sob forma amedrontadora e monstruosa, tal como a do apapãiyei aintyá, mas esta é uma aparência externa. Suas peles são revestimentos (naii) que podem abrir, como explicou um informante « como mala provida de zíper ». Atrás das máscaras amedrontadoras e abaixo das horriveis vestimentas, estão os espíritos reais, de aparência muito semelhante aos Mehinako, mas sem idade e fisicamente perfeitos. Estes espíritos são, apesar disso, perigosos, pois eles podem « levar » (etuka) a alma de uma pessoa (Gregor 1982, p. 312).

É muito sugestiva a imagem de uma «mala provida de zíper » para explicar a natureza transformacional dos seres extra-humanos, no entanto, esta não é simplesmente uma imagem metafórica, mas a imagem concreta de como são as « roupas » desses seres. Antes de prosseguirmos com a definição da noção de "roupa », é necessário esclarecer duas categorias básicas que fundamentam a ontologia wauja, kumã e mona.

A ontologia wauja abrange três macrocategorias : os humanos ou de aparência humana (seres $\tilde{y} \tilde{a} u$ ), os animais, as plantas e os artefatos (seres mona) e os monstros (seres kumã, divididos em yerupoho, apapaatai iyajo e apapaatai onaĩ, ou simplesmente apapaatai). Os termos mona e kumã atuam como modificadores lingüísticos da natureza das coisas e seres do mundo, ordenando-os em uma escala contínua e flexível das subcoisas às supercoisas ( $c f$. também Viveiros de Castro $1977 \mathrm{e} 1978$ ). A categoria kumã (kumalu, feminino), que significa arquetípico, extraordinário, monstruoso, gigantesco, perigoso, poderoso e / ou invisível, aplica-se aos apapaatai e aos yerupoho, mas em determinados contextos grandes animais predadores também podem ser percebidos como tendo uma natureza kumã. A maioria dos seres verdadeiramente kumã possui, além de sua dimensão monstro, uma dimensão visível e enfraquecida, representada pelos seres e coisas mona, termo que, nesse caso específico, significa 


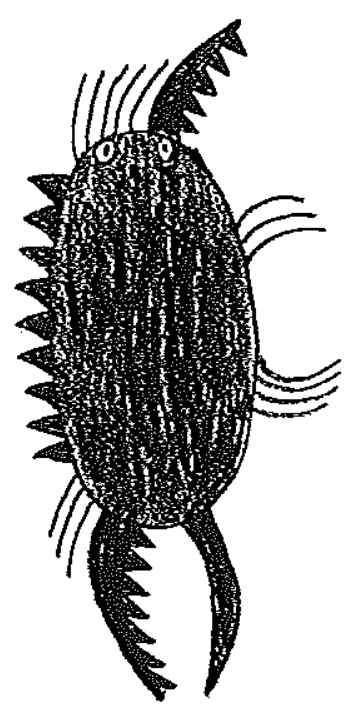

5

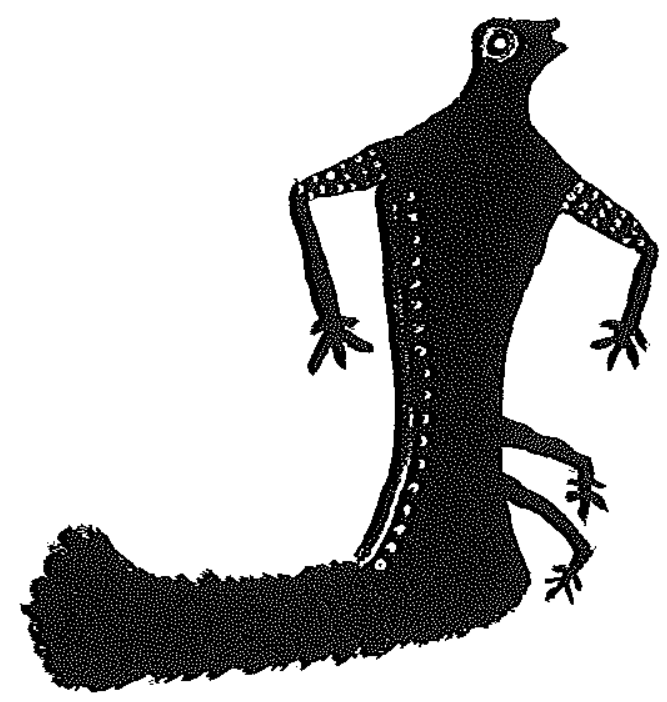

6

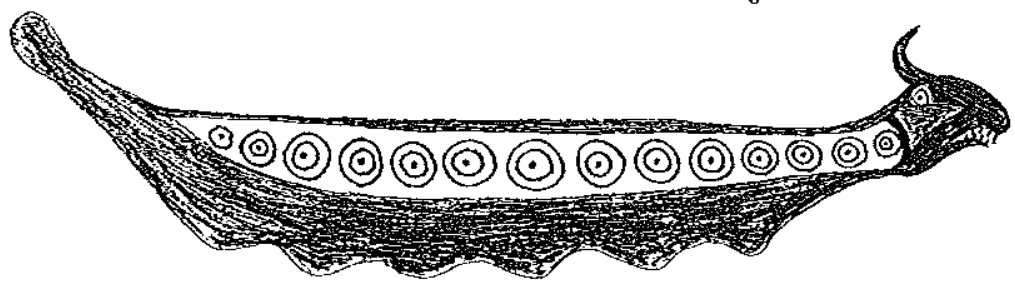

7

Fig. 5. - Eyıısi kumã, apapaatai ijajo (rã-monstro) Autor : Kamo Wauja

Técnica : crayon s/ canson. Dimensões : $25 \times 30 \mathrm{~cm}$ Coleçào Aristóteles Barcelos Neto (1998)

FIG. 6. - Meyejo kumã, apapaatai iyajo (gambá-monstro) Autor : Kamo Wauja

Técnica : crayon s/ canson. Dimensões : $30 \times 50 \mathrm{~cm}$ Coleção Aristóteles Barcelos Neto (1998)

FIG. 7. - Mepelesi kumã, apapaatai iyajo (sanguessuga-monstro) Autor : Kamo VVauja

Técnica : crayon s/ canson. Dimensòes : $30 \times 50 \mathrm{~cm}$ Coleção Aristóteles Barcelos Neto (1998) 

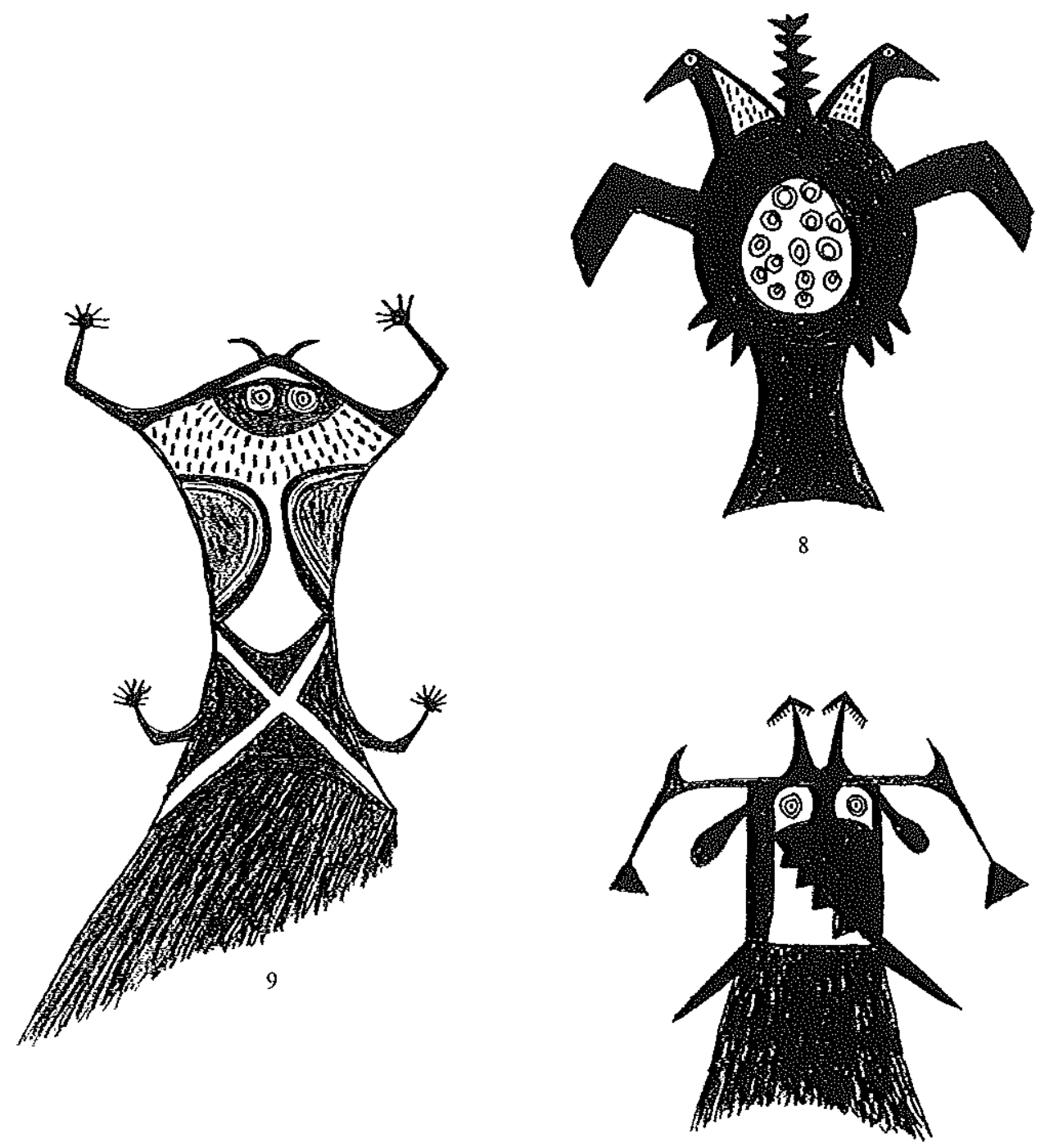

10

FIG. 8. - Kảkãya kumă, apapaatai iyajo (pássaro-monstro) Autor : Kamo Wauja

Técnica : crayon s/ canson. Dimensòes : $25 \times 30 \mathrm{~cm}$ Coleção Aristóteles Barcelos Neto (1998)

FIG. 9. - Eyusi kumã, apapaatai onaĩ (« roupa » rã-monstro) Autor : Kamo IVauja

Técnica : crayon s/ canson. Dimensões : $30 \times 50 \mathrm{~cm}$ Coleção Aristóteles Barcelos Neto (1998)

FIG. 10. - Talapi kumă, apapaatai onaì (« roupa » peixe-clarinete monstro) Autor : Kamo Wauja

Técnica : crayon s/ canson. Dimensões : $25 \times 30 \mathrm{~cm}$ Coleção Aristóteles Barcelos Neto (1998) 
visível, ordinário e comum, correspondendo aos artefatos, plantas e animais palpáveis, aos quais os Wauja identificam de acordo com seus hábitats fixos e comportamentos alimentares previsíveis. Em linhas gerais, trata-se de um sistema em que cada coisa ou ser possui um « duplo » co-extensivo de natureza monstruosa. Tais monstros são dotados de extrema inteligência, de pontos de vista próprios e de uma sensibilidade artística especial, revelando-se perigosos, maliciosos e criativos, sendo a maioria feiticeiros e, alguns, antropófagos. São estes os seres que deffagram a vingança pela predação humana de um ser mona, lançando feitiços ou roubando e devorando as almas humanas.

Os yerupoho, em função de sua impressionante ambigüidade «gente-animal » ou « gente-artefato » e das suas possibilidades transformativas, constituem a mais complexa dessas categorias de seres. Como os yerupoho apresentam as duas naturezas, $\tilde{y}$ ãu e kumã (há inclusive vários deles conhecidos como ĩyãu kumã e ̃̃yãu kumalu, ou seja, homem-monstro e mulher-monstro respectivamente), os Wauja os percebem simultaneamente como " gente » e monstro. O casal de panelas-monstro da Figura 1 são yerupoho canibais, suas relações de identidade corporal voltam-se tanto para o corpo humano quanto para as enormes panelas de cerâmica produzidas pelos Wauja - observe os seus tórax arredondados e as suas peles escuras como a fuligem, características corporais próprias das panelas. Já o homem-rã da Figura 3 mantém relações de identidade com as rãs (Figura 4) que nadam nas lagoas onde os Wauja pescam.

A natureza transformacional dos seres extra-humanos baseia-se na noção de « roupa » (naĩ) que pressupõe que seres « sobrenaturais antropomorfos » (os yerupoho) podem se «vestir» com formas de animais, plantas, artefatos domésticos, instrumentos musicais e fenômenos naturais. Ou seja, a "roupa » é uma exterioridade animal ou monstro que recobre uma interioridade antropomorfa ou zooantropomorfa, conhecida como yerupoho. A « roupa » é a obra de arte da transformação, uma forma exterior singular e criativamente elaborada pelas alteridades extra-humanas para estabelecerem diferentes identidades. Ressalto que as « roupas » não são corpos (omonapitsi). Apenas os yerupoho, os humanos e os apapaatai iyajo são corpos, todos os outros seres, inclusive os mais pequeninos insetos, são « roupas ».

A versatilidade na fabricação destes seres é imensa : eles podem ser criados aos milhares, e cada um deles pode apresentar diferentes motivos gráficos e formas anatômicas. Dentre as matérias-primas mais importantes de uma « roupa » estão os motivos gráficos « geométricos » e as cores que a singularizam, tal qual numa estampa de tecido desenhada por encomenda a um estilista. Para os Wauja, muitas « roupas » têm requintes de perfeição formal que se tornam objetos de especial interesse estético e ritual. As aves e depois as cobras são tidas como as mais belas criações nesse sentido.

Através das « roupas », alguns yertipoho podem mudar; dependendo de suas intenções, de peixe para ave, de inseto para réptil, de mamífero para anfíbio, de raposa para cobra, etc., apontando para um fluxo aparentemente infindável de transformações no cosmo wauja (conforme quadro abaixo). 
Transformaçōes gerais dos seres extra-humanos

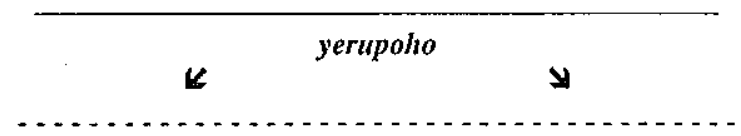

apapaatai kumã $\leftrightarrow \leftrightarrow \leftrightarrow \leftrightarrow \leftrightarrow$ objetos e seres mona

$\boldsymbol{Y}$ transformações permanentes (sem * roupa *) ou temporítias (com * roupa *)

- . - . - . - Fronteira tênue, ambigüidade, co-extenșão ontológica

$\leftrightarrow$ relaçōes de substância vítal, de « dono » e de identidade corporal ; ambigấidade classificatơria

$\mathrm{Na}$ ontologia wauja, as relações entre os seres extra-humanos apresentam-se como uma tríade, que liga o yerupoho (o ser antropomorfo que se transforma em apapaatai), o próprio apapaatai (a « roupa » vestida pelo yerupoho na transformação) e o animal, planta, fenômeno natural ou artefato (que confere ou inspira a forma corpórea do apapaatai). Esta, porém, é uma relação existente apenas entre uma dada " espécie » e seus «donos sobrenaturais", e não uma relação indistinta, que envolva toda e qualquer « espécie ». Existe uma tríade, por exemplo, entre a rã (ser mona, Figura 4), as rãs-monstro apapaatai iyajo e onã (seres kumãa, Figuras 5 e 9 respectivamente) e a rà-gente (yerupoho, ser antropomorfo, também kumãa, Figura 3); as três últimas sendo as « donas » da rã. É importante esclarecer que os três tipos de seres mencionados são percebidos como co-extensivos porque compartilharam uma mesma alma (paapitsi).

Relação triádica entre os seres extra-humanos

baseada no princício de co-extensão ontológica

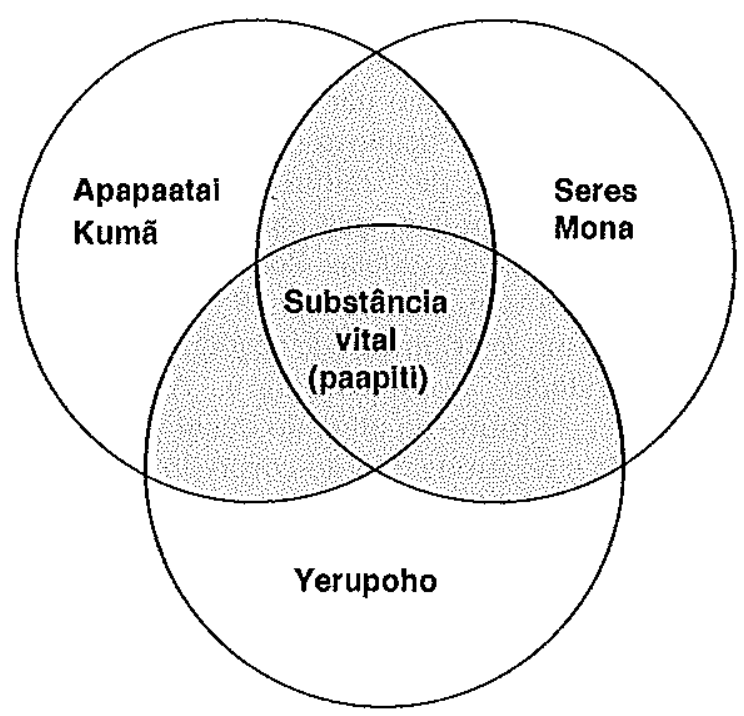


O princípio de interseção da substância vital implica que a periculosidade dos "sobrenaturais " também está implícita e potencialmente presente na dimensão ordinária e visível (mona) dos seres. Tal princípio complementa a idéia das transformações, a qual está diretamente associada à fronteira virtual entre os seres mona $\mathrm{e}$ ktmmã e sua ambigüidade/continuidade. As diferenças entre animais e monstros seriam, portanto, muito mais de grau do que de natureza.

\section{CONCLUSÃo}

Procurei ao longo do artigo mostrar que a experiência visual, ao produzir desenhos ou não, tem um valor reflexivo sobre a alteridade. Muito do que se pode aprender sobre a cosmologia wauja reside no próprio prazer e interesse wauja em organizar visualmente o seu mundo numa série de informações que só podem ser claramente acessados através das imagens. Não digo isso apenas em relação aos desenhos figurativos (potalapitsi) que coletei, mas a todo o conjunto da cultura material e dos motivos gráficos « geométricos ».

As imagens indicam como os humanos pensam o seu lugar no mundo e como devem ser as suas relações com as alteridades extra-humanas. Para estes seres, cheios de desejo por carne e almas humanas, os Wauja não passam, do ponto de vista dessas mesmas alteridades, de uma expressão ontológica frágil, embora interessante e atraente. Na vastidão dos espaços do cosmo wauja, tudo o que não é moral e fisicamente próximo da noção wauja de humanidade ideal constitui um inimigo potencial, podendo vir a conspirar contra os próprios Wauja. Do nascimento à morte, estes índios concebem suas vidas estreitamente ligadas àquilo que os afrontam e thes causam medo : os apapaatai e yerupoho.

Em torno das relações com as alteridades extra-humanas, surgem estruturas políticas e rituais que amalgamam as relações de reciprocidade entre os Wauja através da redistribuição de comida e de serviços rituais (construção de casas, plantio de roças e produção de artefatos de uso doméstico). Ao que tudo indica, o circuito simbólico dessas estruturas parece emergir do complexo da doença.

A pertinência política do xamanismo não se revela apenas no tão referido jogo faccional e no fluxo de reciprocidade negativa que se objetivam na adivinhação das causas das doenças, em acusações de "feitiçaria », no medo a estas e em atos defensivos de caráter mágico-simbólico, que configuram uma permanente guerra simbólica interna às aldeias e entre as aldeias. Pois o xamanismo xinguano, além de poderoso « oráculo policial » (Menezes Bastos 1995), que funciona no âmbito das acusações de « feitiçaria », é um instrumento de negociação das almas e de mediação do conflito com as alteridades "sobrenaturais ». A doença em estado grave manifesta-se sempre através do roubo da alma do doente por um apapaatai. O papel do xamã wauja é resgatá-la e reintroduzi-la no corpo do doente, evitando assim sua morte em consequiência da perda definitiva da alma. O resgate da alma do doente é negociado tête à tête com o apapaatai que a roubou, nesse momento o xamã assume o papel de um diplomata que promete, em nome do doente, festa e comida ao apapaatai.

Seguindo essas observações, sugiro, como hipótese, que os xamãs são os renovadores, em primeira instância, do contrato cósmico, o qual pressupõe, entre outras coisas, o estabelecimento de uma relação de reciprocidade positiva entre as diferentes 
realidades ontológicas (homens e monstros). Ainda no âmbito do contrato cósmico, arrisco a hipótese de que um dos seus aspectos fundamentais é evitar que seres humanos sejam metafisicamente transformados em apapaatai. Estaria então sob o poder do xamã manter cada realidade ontológica em seu lugar. Ao negociar o retorno das almas humanas roubadas, o xamã evitaria a permanência definitiva das almas nos mundos dos monstros e sua "ressocialização » entre estes últimos.

Tomando a evidência das relações de reciprocidade forçada entre os Wauja e as alteridades monstruosas, sugiro ainda a hipótese de que a política cósmica ( $f$. Viveiros de Castro 1996) wauja estaria todo o tempo operando no sentido da conversão dos domínios associais, utilizando-se de dispositivos como a arte e a oferta de comida, objetivadas nas festas de apapaatai. Por outro lado, a própria festa se converteria em acumulação de « prestígio ritual » para o doente e para o xamã que respectivamente a patrocinou e organizou. $\mathrm{O}$ referido " prestígio » parece advir da disposição do doente (sempre auxiliado por sua parentela consangüínea e / ou co-residentes) e do xamã (sempre auxiliado pelo apapaatai que originalmente o adoeceu) em controlar o associal (caracterizado pelas manifestações do poder maléfico das alteridades « sobrenaturais »), evitando o desequilibrio entre as duas realidades ontológicas. Seguindo esse raciocínio, as festas de apapaatai seriam o momento final e supremo da superação de uma situação liminar (a doença) em que um ente wauja (humano) esteve prestes a se transformar metafisicamente num outro (monstro). Nesse sentido, as festas de apapaatai apontam para um jogo simbólico de reelaboração / reprodução da identidade e da alteridade entre os Wauja, jogo este caracterizado como uma experiência eminentemente artística.

* Manuscrit reçu en janvier 2000, accepté pour publication en mars 2001.

NOTAS

Agradecimentos

Agradeço à FAPESP, à CAPES, ao FUNPESQUISA / UFSC, ao CADCT / Governo do Estado da Bahia e ao Museu Nacional de Etnologia os apoios financeiros concedidos para a realização dos trabalhos de campo e das análises dos dados. Sou também grato aos Wauja, especialmente aos meus informantesdesenhistas Kamo, Itsautaku, Aulahu, Ajoukumã e Aruta. Pedro Agostinho da Silva, Maria Rosário Carvalho, Ana Maria Gantois, Vera Penteado Coelho, Rafael de Menezes Bastos, Lux Vidal, Bruna Franchetto, Carlos Fausto, Michael Heckenberger e Joaquim Pais de Brito contribuíram com valiosos comentários e incentivos à minha pesquisa entre os Wauja.

1. Fénelon Costa (1988), Gebhart-Sayer (1985 e 1986), Gow (1988 e 1999), Guss (1989), Lagrou (1998), Langdon \& Baer, orgs. (1992), Luna \& Amaringo (1991), Ribeiro (1986), Velthem (1995), Vidal, org. (1992), entre outros.

2. O leitor encontrará na literatura xinguana o termo " Waurá ", que é o etnônimo difundido desde von den Steinen (1886 e 1894). Optei por grafar « Wauja " por este ser exatamente o etnônimo auto-atribuído.

3. Dados censitários de outubro de 2000.

4. O leitor encontrará nas monografias de Münzel (1971), Viveiros de Castro (1977), Gregor (1982) e nos artigos de Dole (1964), Carneiro (1977), Menezes Bastos (1984-1985) e Coelho (1988) descriçòes e análises de diferentes aspectos do xamanismo xinguano.

5. Nas palavras wauja, a vogal /o/ está convencionada como alta central fechada não-arredondada. 
6. Os yakapá formam uma comunidade « panxinguana », sendo aparentemente a sua « capital » a aldeja kamayurá de Ipavu, a qual é referida pelos Wauja como um lugar de aprendizado e de xamãs de grande poder que têm exercido fascínio e interesse para além das fronteiras do mundo xinguano (Menezes Bastos 1984-1985 e 1995).

7. Sobre a questão das relações entre a feitiçaria e o faccionalismo político wauja vide Ireland (1986, 1988 e 1993).

8. Pulu Pulu é a árvore usada para se fazer um instrumento musical de percussão homônimo (" trocano ") em português). O instrumento, em si, é considerado um apapaatai, e residência de alguns outros. Assim como as flautas kawokh, o Pulu Pulu está envolto de proibição visual por parte das mulheres. A última festa de $P$ ulu Pulu na aldeia wauja foi realizada em 1947. A única descrição diz tratar-se de « um grande tronco de árvore completamente oca, aberto nas extremidades, medindo pouco mais de um metro de diâmetro estendendo-se em todo o comprimento da casa [dos homens]. Êsse tronco apresentava ainda đesenhos vários, na maioria zoomorfos, por tôda a sua parte externa » (Lima 1950, p. 7).

9. Os nomes dos seres extra-humanos reconhecidos por apapaatai e yertupoho aparecem em maiúsculo enquanto o dos animais e artefatos, em minúsculo. Por exemplo : Kukuho refere-se ao apapaatai (o « espírito ») e kukuho à larva sphingidade sp. (o animal), e Kawoká e kawoká, respectivamente, ao apapaatai e à flauta.

10. espaço deste artigo não me permite descrever os pormenores do complexo sistema do adoecimento. De um modo geral a doença (ou seja, o ataque de um apapaatai) é deflagrada pela quebra de tabus alimentares, sexuais e laborais e quando a pessoa tem wìtsixuki, noção que pode ser aproximadamente traduzida pela não satisfação de um desejo alimentar e pelo esquecimento ou recusa de alimentar-se regularmente. Enfim, o que deflagra a doença são as negligências sobre si próprio ou sobre os filhos pequenos.

11. Entre os Sanumá, espíritos « sobrenaturais » aproveitam o corpo do xamã para viver en seu peito e conseguir uma pseudocorporalidade (Taylor 1976, pp. 45-47). A idéia de que seres extra-humanos residem dentro do corpo do xamã é um aspecto fundamental nos xamanismos sanumá (Taylor 1996) e wauja, apontando para as suas naturezas transespecíficas e ao mesmo tempo ambíguas (Viveiros de Castro 1977, pp. $220 \cdot 232$ e 1996 , pp. $117-120$ ).

12. Esse tipo de feitiço é chamado pelos Wauja de ìyãu opotalá (maleficio de gente ; coisa vil feita por humano), o qual se difere de apapaatai onukula (flecha de feitiços « sobrenaturais »).

13. A humanidade foi (re)criada a partir de pedaços de pau, que se tornaram vivos após a pintura, a defumação e a música executadas pelo demiurgo. As versões completas do mito de origem wauja encontram-se em Schultz (1965) e Mello (1999) e as versões kamayurá em Villas Boas \& Villas Boas (1970) e Agostinho (1974).

14. As considerações Mehinako (Gregor 1982, pp. 316-320) e Yawalapíti (Viveiros de Castro 1977, pp. 225-229) a respeito dessa questão apresentam absoluta correspondência com o que pude observar entre os Wauja.

\section{REFERÊNCIAS BIBLIOGRÁFICAS}

Agostinho, Pedro, 1974. - Kwarip. Mito e ritual no Alto Xingu, EPU / EDUSP, São Paulo .

Barcelos Neto, Aristóteles, 1999. - Arte, estética e cosmologia entre os índios Waurá da Amazônia Meridional, Dissertação de Mestrado em Antropologia Social, Universidade Federal de Santa Catarina, Florianópolis.

CARNEIRO, Robert, 1977. - « Recent Observations on Shamanism and Witchcraft among the Kuikuro Indians of Central Brazil » Annals of the New York Academy of Sciences, 293, Nova York, pp. 215-228.

Coklho, Vera Penteado, 1988. - «Informações sobre um instrumento musical dos índios Waurá », Revista do Museu Paulista, nova série, 33, São Paulo, pp. 193-224.

—, 1991-1992. - « Figuras antropomorfas nos desenhos dos índios Waurá 》, Schweizerische Amerikanisten Gesellschaft, 55-56, Basiléia, pp. 57-77. 
DoLe, Gertrude, 1973 (1964). - « Shamanism and Political Control among the Kuikuro », in : Daniel Gross (org.), Peoples and Cultures of Native South America, The Natural History Press, Nova York, pp. 294-307

FÉnelon Costa, Maria Heloísa, 1988. - O mundo dos Mehinaku e suas representações visuais, Editora UnB, Brasilia.

Franchetto, Bruna, 2001. - «Línguas e história no Alto Xingu », in : Bruna Franchetto e Michael Heckenberger (orgs.), Os povos do Alto Xingu : história e cultura, Editora UFRJ, Rio de Janeiro, pp. 111-156.

GebHart-Sayer, Angelika, 1985. - « The Geometric Designs of the Shipibo-Conibo in Ritual Context », Journal of Latin American Lore, 11(2), San Francisco, pp. 143-175.

—, 1986. - « Una terapia estética : los diseños visionarios del ayahuasca entre los ShipiboConibo ", America Indígena, 46, Bogotá, pp. 189-218.

Gow, Peter, 1988. — « Visual Compulsion : Design and Image in Western Amazonian Cultures », Revindi, 2, Budapest, pp. 19-32.

-, 1999. - - " Piro Designs : Painting as Meaningful Action in an Amazonian Lived World », Journal of the Royal Anthropological Institute, new series, 5, London, pp. 229-246.

Gregor, Thomas, 1982. - Mehinaku : o drama da vida diária em uma aldeia do Alto Xingu, Cia. Editora Nacional, São Paulo.

Guss, David, 1989. - To Weave and Sing : Art Symbol, and Narrative in the South American Rain Forest, University of California Press, Berkeley e Los Angeles.

Heckenberger, Michael, 1996. - War and Peace in the Shadow of Empire: Sociopolitical Change in the Upper Xingu of Southeastern Amazonia, A.D. 1400-2000, Tese de Doutorado, Universidade de Pittsburg, Pittsburg.

-, 2001. - «Estrutura, história e transformação: a cultura xinguana na longue durée, 1000-2000 d.C. », in : Bruna Franchetto e Michael Heckenberger (orgs.), Os povos do Alto Xingu : história e cultura, Editora UFRJ, Rio de Janeiro, pp. 21-62.

IRELAND, Emilienne, 1986. — « Our chiefs do not spill their anger : covert leadership in political decisions ", paper presented at the $85^{\text {th }}$ AAA, in the session Political Structure and Law of Autocracies and Dictatorships, Philadelphia.

-, 1988. — « Killing a public menace or a private enemy ? Revenge and witchcraft execution », paper presented at the $87^{\text {th }}$ AAA, in the session Murder, Feud, and Revenge, Phoenix.

-, 1993. - «Witchcraft accusations and political succession in a Xingu Society », paper presented at the Conference on Lowland South America Indians, Bennington College, Bennington, Vermont.

LAGRou, Elsje Maria, 1998. - Caminhos, duplos e corpos : uma abordagem perspectivista da identidade e alteridade entre os Kaxinawa, tese de Doutorado em Antropologia Social, Universidade de São Paulo, São Paulo.

LANGDON, Esther Jean and Gerhard BAER, (orgs.), 1992. - Portals of Power : Shamamism in South America, New Mexico University Press, Albuquerque.

L.Évi-STrauss, Claude, 1989. - O pensamento selvagem, Papirus, Campinas.

Lima, Pedro E., 1950. — "Os índios Waurá. Observações gerais. A cêramica », Boletim do Museu Nacional, nova série, Antropologia, 9.

Luna, Luis Eduardo and Pablo Amaringo, 1991. - Ayahuasca Visions : The Religious Iconography of a Peruvian Shaman, North Atlantic Books, Berkeley. 
Mello, Maria Ignez, 1999. - Música e mito entre os Wauja do Alto Xingu, dissertação de Mestrado em Antropologia Social, Universidade Federal de Santa Catarina, Florianópolis.

MENEzes BASTos, Rafael de, 1984-1985. — « O Pajemeramaraká kamayurá : uma contribuição à etnografia do xamanismo no Alto Xingu », Revista de Antropologia, 27-28, pp. 139-177.

-, 1995. - «Indagação sobre os Kamayurá, o Alto Xingu e outros nomes e coisas : uma etnologia da sociedade xinguara ", Anuário Antropologico, 94, pp. 227-269.

MÜNZeL, Mark, 1971. - Medizimmannwesen und Geistervorstellungen bei den Kamayurá (Alto Xingú-Brasilien), Franz Steiner Verlag GMBH, Wiesbaden.

ReICHEL —Dolmatof, Gerardo, 1978. — Beyond the Milk Way': Hallucinatory Imagery of the Tukano Indians, University of California, Latin American Center Publications, Los Angeles.

RiBEIRo, Berta (org.), 1986. - Suma Emológica Brasileira, Arte Índia (vol. 3), Vozes, Petrópolis.

Schultz, Harald, 1965. — «Lendas waurá », Revista do Museu Paulista, nova série, 4, pp. 21 150.

SEeger, Anthony, 1981. - Nature and Society in Central Brazil: The Suya Indians of Mato Grosso, Harvard University Press, Cambridge.

SteInen, Karl von den, 1942 [1886]. - O Brasil Central, Cia. Editora Nacional, São Paulo.

—, 1894. -- Unter den Naturvökern Central-Brasiliens, Dietrich Reimer, Berlin.

TAYLOR, Kenneth, 1976. - « Body and Spirit among the Sanuma (Yanomami) of noth Brazil », in : F. Grollig and H. HALEY (org.), Medical Anthropology, Mouton, Haia, pp. 27-48.

—, 1996. — «A geografia dos espíritos : o xamanismo entre os Yanomami setentrionais », in : Esther Jean LANGDON (org.), Xamanismo no Brasil : novas perspectivas, Editora da UFSC, Florianópolis, pp. 117-151.

URBAN, Greg, 1992. - " A história da cultura brasileira segundo as línguas nativas ", in : Manuela CARneIro Da CunHa (org.), História dos Índios no Brasil, FAPESP, SMC, Companhia das Letras, São Paulo, pp. 87-102.

Velthem, Lucia Hussak van, 1995. - O belo é a fera : a estética da produção e da predação entre os Wayana, tese de Doutorado em Antropologia Social, Universidade de São Paulo, São Paulo.

VIDAL, Lux (org.), 1992. - Grafismo indigena. Estudos de antropologia estética, Studio Nobel / FAPESP, EDUSP, São Paulo.

VILLAS-BoAs, Orlando e Cláudio, 1970. —Xingu : os índios e seus mitos, Zahar, Rio de Janeiro.

Viveiros de CAStro, Eduardo, 1977. - Indivíduo e sociedade no Alto Xingu : os Yawalapíti, dissertação de Mestrado em Antropologia Social, Museu Nacional/UFRJ, Rio de Janeiro.

—, 1978. - «Alguns aspectos do pensamento Yawalapíti (Alto Xingu) : classificações e transformações ", Boletim do Museu Nacional, 26, Rio de Janeiro.

—, 1996. - « Os pronomes cosmológicos e o perspectivismo ameríndio », Mana. Estudos de Antropologia Social, 2(2), pp. 115-144. 